REVIEW OF HISTORICAL SCIENCES 2017, VOL. XVI, NO. 3

http://dx.doi.org/10.18778/1644-857X.16.03.13

Matgorzata Karkocha

UNIVERSITY OF LODZ*

\title{
The painting Assumption of the Blessed Virgin Mary in the parish church in Rembieszyce The history of one artefact
}

$\mathrm{R}$

embieszyce is a small town (approx. 320 inhabitants) situated in the Swiętokrzyskie Voivodship, in the county of Jedrzejow, by the Biała Nida river. The parish church of the Holy Apostles Peter and Paul is located there. Funded by the local heir Franciszek Saryusz Wolski, the vice-voivode of Chęciny (d. 1838) ${ }^{1}$,

* The Faculty of Philosophy and History, The Institute of History, The Department of Modern History / Wydział Filozoficzno-Historyczny, Instytut Historii, Katedra Historii Nowożytnej, e-mail: malkarkocha@o2.pl.

${ }^{1}$ Little is known about his person. Franciszek Saryusz Wolski was the son of Stanisław, the vice-voivode of Chęciny, owner of Czerwona Wola and Zasławice. He had brother Adam and sister Barbara $-1^{\circ}$ voto Lubańska, $2^{\circ}$ voto Łempicka. He was the bearer of Jelita coat of arms. The tombstone inscription states that Wolski was born ca. 1759, and died on September 1, 1838, at the age of 79. As the vice-voivode of Checciny, he is mentioned in the sources from 1778 and 1794, as well as on the bell he founded in 1798. He was also the heir of the nearby Wola Tesserowa, Wegleszyn and the Gałkowie estate in Silesia. The last property was probably brought to him as dowry by his wife, unknown by name, the daughter of Andrzej Gorny Wysocki (d. 1801) and Zofia of the Szczepkowski family (d. 1808). F. Saryusz Wolski as well as his parents-in-law were buried in the cemetery of the Rembieszyce parish. The grave of F. Saryusz Wolski and the tombstones of Andrzej and Zofia Wysocki survived to the present. See S. Borkiewicz, Z. Linowski, Monografia historyczna i gospodarcza powiatu jędrzejowskiego, Kielce 1937, pp. 171-172, p. 217; M. Rawita-Wita nowski, Dawny powiat chęcinski, ed. D. Kalina, Kielce 2001, p. 477; C. Hadamik, D. Kalina, E. Traczyński, Miasto i gmina Małogoszcz [Series: Dzieje i zabytki małych ojczyzn, ed. R. Mirowski], Kielce 2006, pp. 144-145; M. Karko ch a, Parafia Rembieszyce 1438-2012. Studium z dziejów społeczności lokalnej, Łódź 2013, p. 23, pp. 61-62 and the 


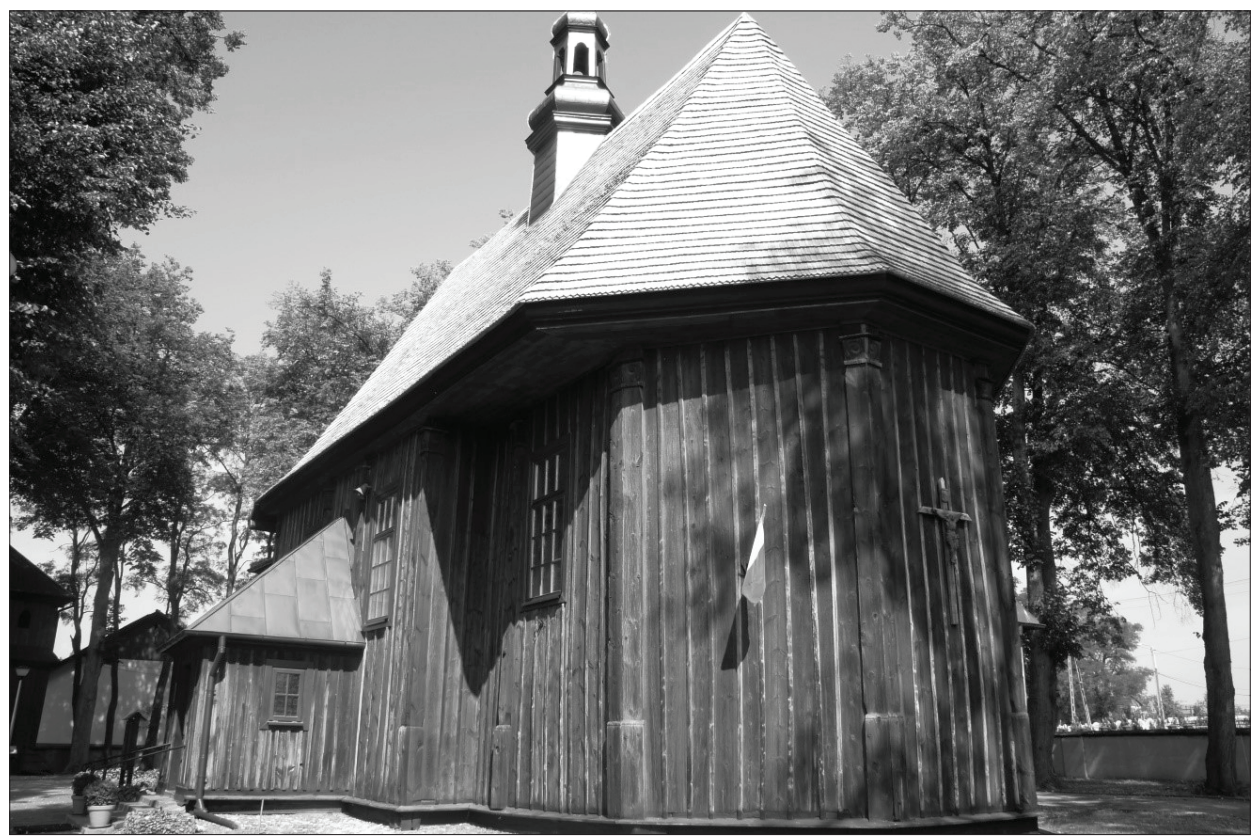

1. The parish church in Rembieszyce, a view from the south-eastern side, 2012. Photo credit: M. Karkocha

it was erected in the years 1798-1799, constituting the third parish church built in this town. The oldest church from 1438 fell into ruin and was demolished in the mid- $18^{\text {th }}$ century. Another religious building that had been put up in its place (on the initiative of Parish Priest Ludwik Sakiewicz) survived only 40 years; it was burnt in mysterious circumstances between 1791 and $1795^{2}$.

The church financed by F. Saryusz Wolski is a wooden structure, in which post-and-plank and log constructions are combined. It has one nave built on a plan of a rectangle, almost a square. Its equally high but narrower chancel is shallow, rectangular and enclosed on three sides. A square sacristy adjoins the chancel on the northern side, and a small, square porch is located on the southern wall of the church. Another rectangle porch is situated

following. For the contents of inscriptions on the graves of the above-mentioned, see ead e m, Zabytki epigraficzne $w$ Rembieszycach z XV-XIX wieku, "Studia Epigraficzne" 2016, vol. VI, p. 44, pp. 53-55.

2 M. Karko cha, Parafia Rembieszyce..., p. 42 and the following; J. W is s n i ewski, Historyczny opis kościołów, miast, zabytków i pamiątek w Jędrzejowskiem, Mariówka 1930, p. 334. 
on the western side. This porch was originally smaller and served as a belfry. In the sixties of the $19^{\text {th }}$ century it was rebuilt and opened to the interior of the nave.

The nave and the chancel have one, common gable roof - with a king post truss, with three slopes over the termination of the chancel, covered with wood shingles. In the middle of the ridge of the roof there is a hexagonal turret with a Sanctus bell (fleche) and an arcaded lantern, topped by a helmet-shaped roof with a spire and a double iron cross. The hipped roof over the former belfry forms a pear-shaped cupola in its upper part and is crowned with a cross. The roofs over the sacristy and the lateral porch are three-sloped. Originally, they were covered with wood shingles, later replaced with sheet metal.

The light pours into the church through eight rectangular windows of various size: four are situated in the aisles, arranged symmetrically on each side, one in the chancel on the southern side, and the rest in the western porch. In addition, one small window is found on the eastern side of both, the sacristy and the southern porch. The exterior walls of the building are covered with vertical boards, fixed with batten. The walls are reinforced with the studs in the form of pilasters which are supported on plinths and topped by the capitals with volutes turned inwards. On the siding, the bases of pilasters are plain, and inside the church they are profiled and fluted ${ }^{3}$.

Admittedly, Franciszek Saryusz Wolski was generous when it comes to the church. The sources indicate that it was built of good quality wood while its interiors were adorned by a well-known painter from Cracow, Michał Stachowicz (1768-1825) ${ }^{4}$. According to the

${ }^{3}$ Katalog zabytków sztuki w Polsce, vol. III (Województwo kieleckie), ed. J.Z. Łoziński, B. Wolff, issue 3 (Powiat jedrzejowski), ed. T. Przypkowski, Warszawa 1957, p. 33; M. Karkocha, Parafia Rembieszyce..., pp. 175-176, 297-298; C. Hadamik, D. Kalina, E. Traczyński, op. cit., p. 207; J. Wiśniewski, op. cit., p. 335; A. Adamczyk, T. Wróbe1, Kościoły drewniane w województwie świętokrzyskim, Kielce 2010, p. 68; R. Mirowski, Kościoły drewniane: najbardziej polskie..., Warszawa 2005, p. 168; also: The Voivodship Heritage Monuments Protection Office in Kielce [further on: WUOZwK], Kościół pw. Świętych Piotra i Pawła w Rembieszycach, record sheet, ed. S. Fiedorczuk, 1987.

${ }^{4}$ On the subject of Stachowicz and his work, see D. Radwan, Stachowicz Michat Franciszek, [in:] Polski słownik biograficzny [further on: PSB], vol. XLI, Warszawa-Kraków 2002, pp. 327-331; Michał Stachowicz, "Tygodnik Ilustrowany" 1860, No. 28 of March 26, pp. 241-242; A. Grabows ki, Michał Stachowicz i jego prace, "Czas" 1866, No. 167 of July 26, p. 1; i d e m, Wspomnienia Ambrożego Gra- 
accounts of Father Stanisław Kaminski, the administrator of the Rembieszyce parish in 1866-1878, the artist covered the walls and the ceiling of the church with ornamental decorations ${ }^{5}$, created the polychrome of the main and of the three side altars ${ }^{6}$, and did eight paintings that adorned the altars, namely: Sts Peter and Paul, St Stanislaus, St Michael Archangel, St Francis of Paola, Virgin and Child with Saint Anne (or rather Holy Family), St Jude Thaddaeus, St Nicholas, St Catherine of Alexandria, as well as plafonds in the aisles and the chancel depicting Holy Trinity and Assumption of the Blessed Virgin Mary .

bowskiego, ed. S. Estreicher, vol. II, Kraków 1909, pp. 130-140; J. Dobrzycki, Michał Stachowicz, Kraków 1925; E. Ras tawiecki, Słownik malarzów polskich tudzież obcych $w$ Polsce osiadłych lub czasowo $w$ niej przebywajacych, vol. II, Warszawa 1851, pp. 201-212; vol. III, Warszawa 1857, pp. 402-403; J.A. N ow obilski, Mecenat artystyczny Jana Pawła Woronicza w Krakowie, Kraków 2002; and recently Z. Michalczyk, Michat Stachowicz (1768-1825) krakowski malarz między barokiem a romantyzmem, vol. I-II, Warszawa 2011.

5 “... over the walls painted with pearl distemper, dangling garlands of leaves and flowers were scattered - in the middle of them, bigger and smaller oil paintings and watercolors were hung". [Ks. S. Kamiński], The Parish Church in Rembieszyce, no date [further on: S. Kamiński, The Parish Church], The Diocesan Archive in Kielce [further on: ADK], Zbiór dokumentów dotyczacych parafii i kościoła w Rembieszycach 1613-1899, ref. code II PR-IV/1, sheet No. 169.

6 "Three smaller Altars are painted with distemper on plain boards that are topped with a canvas - of the bluish color - and are in accordance with the High Altar - All of it was done by the aforementioned artist, the late Michal Stachowicz". Ibidem, sheet No. $169 \mathrm{v}$.

7 Ibidem, sheet No. 169-169v, 170v-171. According to Z. Michalczyk, Adoration of the Magi located at the final of the side altar (on the gospel side) was also the work of the artist from Cracow, though it is not confirmed anywhere in the archives. See Z. Michalczyk, op. cit., vol. I, p. 51; vol. II, p. 129. Let us add here that Fr. Kamiński [The Parish Church, sheet No. 171-171v] also described the paintings adorning the walls of the church as well as the altar of the Crucified Jesus which does not exist anymore - even though their author is not specified, Stachowicz's authorship cannot be ruled out: “...two bigger watercolors deserve further attention - the first one, hung on the left side of the H. Altar - depicts Jesus Christ kneeling at St Peter's feet with a sheet in his hand and other Apostles watching closely the rite of washing of the feet. The second, opposite the altar of Lord Jesus, depicts the moment in which Christ the Lord entrusts the authority over his Church to Peter. Here again, Symon Cefas kneels at Savior's feel and receives from His hands the keys to the Kingdom of God. There is another watercolor at the altar of Lord Jesus which portrays St Isadore the Farmer, and two small ones on the walls - of St Jerome and of St Pope Gregory, yet they are of lesser importance". The first of these works has survived to our times. It hangs on the wall of the southern aisle, over the entrance to the porch. Its conservation 
The exact date of their creation is unknown. Most likely, they were made after 1802, as the inventory of the church and the benefice of the Rembieszyce parish from that time do not mention anything about the decorations inside the church. Zbigniew Michalczyk, the author of the latest monograph on Stachowicz, dates the said works to ca. 1805. The signature and the inscription on an unsuccessful drawing from the collections of Teodor Stachowicz's heirs ("1805 Michael Stachowicz invenit in Rembieszyce") allowed to establish that the artist from Cracow stayed in Rembieszyce during the period in question ${ }^{8}$. There might be a connection between these works and the series of paintings entitled Images of Saints which was commissioned to Stachowicz by the Chapter of Kielce. As the vicevoivode of Chęciny, Wolski must have visited the town regularly, and probably Kielce as well. He could have learnt about this commission, or even met the painter in person and hired him to decorate the manor house and the newly-erected church ${ }^{9}$. It cannot be ruled out that F. Saryusz Wolski knew the family of the artist's mother, which originally came from nearby Jędrzejów ${ }^{10}$. Stachowicz's artworks appear in the inventory of fundi instructi drawn up after the death of the local parish priest, Andrzej Południkiewicz, in the years $1799-1822^{11}$.

The time was not kind to Stachowicz's works in the church of Rembieszyce. Due to constant damp patches caused by a leaky roof, the wall polychrome got destroyed in the first half of the $19^{\text {th }}$ century $^{12}$. It was covered with paper during full-scale restoration

is planned for 2018. Perhaps this time, it will be possible to uncover the signature of the artist, and confirm or rule out Stachowicz's authorship.

${ }^{8}$ Z. Michalczyk, op. cit., vol. I, p. 50; vol. II, p. 128.

9 E. Schugt also indicates that Stachowicz decorated the manor house in Rembieszyce. I d e m, Kilka słów o Michale Stachowiczu, "Dwutygodnik literacki" [Kraków] 1845, vol. II, p. 75.

10 M.W. Grzeszczuk, Stachowicz Stanisław, [in:] PSB, vol. XLI, WarszawaKraków 2002, p. 332; A. Artymiak, Mieszkańcy miasta Jędrzejowa w świetle najstarszej księgi metrykalnej (1743-1752), Jędrzejów 1947, p. 41, footnote 5, and especially p. 46.

${ }^{11}$ Inwentarz podawczy plebani rembieszyckiej sporządzony po Ś.P. księdzu Andrzeju Południkiewiczu, plebanie rembieskim na dniu siódmym grudnia 1822 zmarłym. Spisany dnia dwudziestego szóstego miesiąca lutego roku tysiąc ośmset dwudziestego trzeciego, ADK, Akta konsystorskie parafii Rembieszyce 1811-1833, ref. code PR-6/1, sheet No. 19v-20.

${ }^{12}$ In his letter to the Consistory of Kielce from 1844, Father Józef Witek, the administrator of the parish in 1827-1853, reports: "the roof on the church is so 
of the building in 1867 which in the twenties of the $20^{\text {th }}$ century was replaced with wall ornaments of figurative, geometric-floral and zoomorphic motifs, painted on a thin levelling layer of lime and adhesive mortar over wood ${ }^{13}$. A similar thing happened to the painting on the ceiling of the nave ${ }^{14}$. At the end of the $19^{\text {th }}$ or beginning of the $20^{\text {th }}$ century, it was replaced with a scene of Transfiguration on the Mount Tabor by unknown artist, based on Rafael Santi's work ${ }^{15}$. Also, some of the altar paintings were destroyed in unknown circumstances. Only six paintings survived as well as one plafond in the chancel, which we will discuss in more detail. Until recently, the plafond was in fairly poor condition. With the passage of time, the leaks from the roof caused the darkening and partial destruction of the painting. In 1946, Tadeusz Przypkowski drew attention to its bad condition in a letter to the voivodship conservation officer in Kielce: "in Rembieszyce, in a wooden church from the late $18^{\text {th }}$ century, the ceiling of the chancel has a canvas spread on it which is covered with an interesting painting of the Assumption (very blackened) and ornaments just like in Lazienki Park in Warsaw. It is rare in here to come across a polychrome in a village church from those times. The specimen is preserved quite well, though its edges came off in many places and are hanging pitifully. It might be a good idea to salvage the polychrome while it can still be done inexpensively"16.

battered that even the paintings on the walls... are becoming undone, the canvas on the ceiling is rotting away and the water is falling into the organ case". J. Witek to the Consistory of Kielce, Rembieszyce August 24, (September 5) 1844, ADK, Akta konsystorskie parafii Rembieszyce 1818-1938, ref. code PR-6/2, sheet No. 73. Before 1867, S. Kamiński wrote: "in the summer, the streams of water flowed through the ceiling and the windows - and in the winter, the altars and the floor were white with snow". S. Kamiński, The Parish Church, sheet No. 170.

13 On the walls of the chancel, pairs of birds and mythical creatures are arranged antithetically and integrated into geometrical figures, while the walls of the nave display floral ornaments and monograms of the names of Jesus and Mary.

${ }^{14}$ Even before 1867, "due to constant leaks, the painting on the ceiling in the nave started cracking and peeling off the walls". S. Ka mińs ki, The Parish Church, sheet No. $169 \mathrm{v}$.

15 It is a reference to the painting Transfiguration of Jesus, done in 1516-1520 and commissioned by Cardinal Giulio de' Medici - later Pope Clement VII, now in the collection of Pinacoteca Vaticana.

16 The State Archive in Kielce, Wojewódzki Konserwator Zabytków II, ref. code 265, p. 1 . 

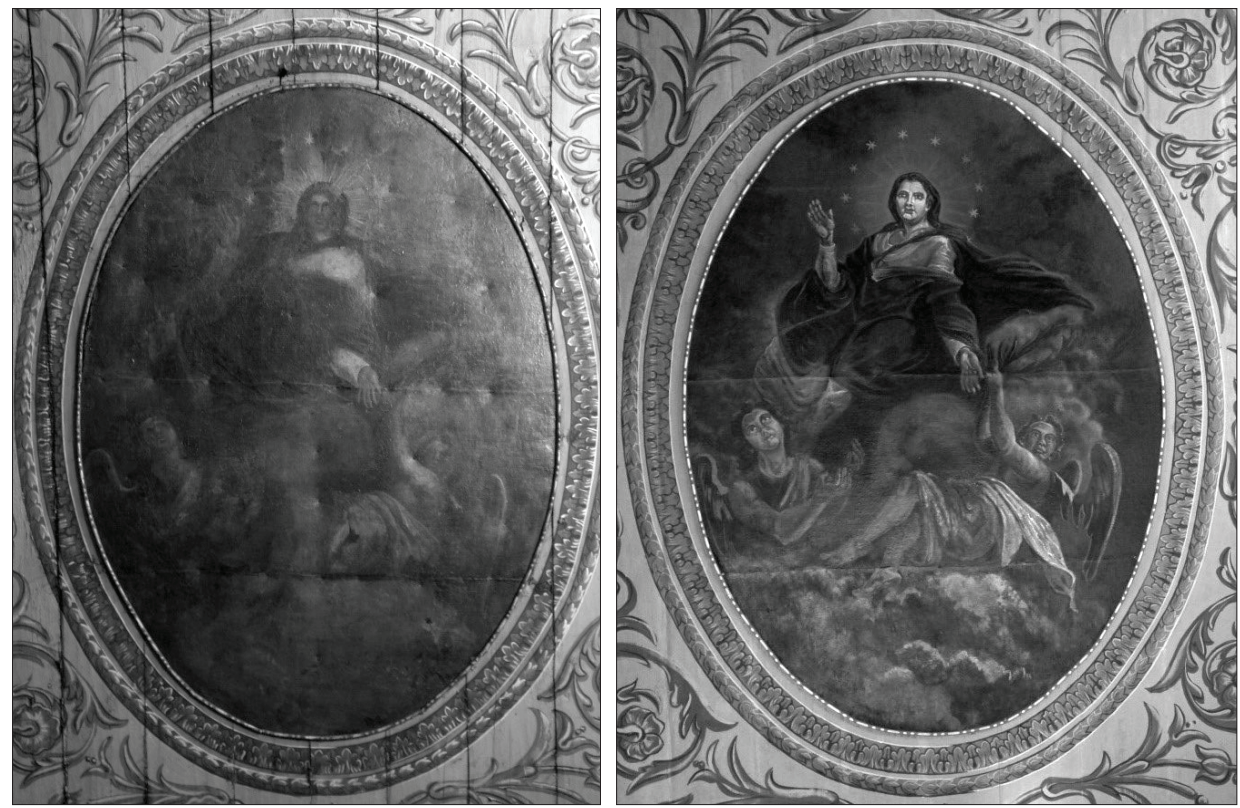

2. M. Stachowicz, Assumption of the Blessed Virgin Mary, the early $19^{\text {th }}$ century, before and after the conservation works in 2017. Photo credit: M. Karkocha

The conservation of the painting was carried out in the fifties of the $20^{\text {th }}$ century ${ }^{17}$, yet very incompetently. Among other things, Mary had two left hands painted (sic!) while her face and the aureole were totally overpainted, ruining the artwork of Stachowicz. The pointilling was not performed properly either. Over time, the layers of varnish blackened, making the composition almost invisible, while in the place of the head of the Mother of God and other parts of the canvas, the paint flaked off and major losses in the paint layer appeared. Here and there, an inherent pattern of cracks (craquelure) was formed on its surface. Only this year, complete conservation works undertaken by Aleksandra and Bernard Kuś allowed to restore the splendor and former beauty of the painting. The process involved disinfecting the canvas, cleaning off the dirt,

17 No detailed information on the matter is to be found in the handwriting sources. What is known, however, is that in 1955 the damaged ceiling of the chancel was being renovated and the paint layer was redone. See Protokól wizytacji dziekańskiej za rok 1955, ADK, Akta kurialne. Protokoły wizytacji dziekańskich 1949-1956, ref. code OD-5/50, sheet No. 196; M. Karkocha, Parafia Rembieszyce..., p. 295. 


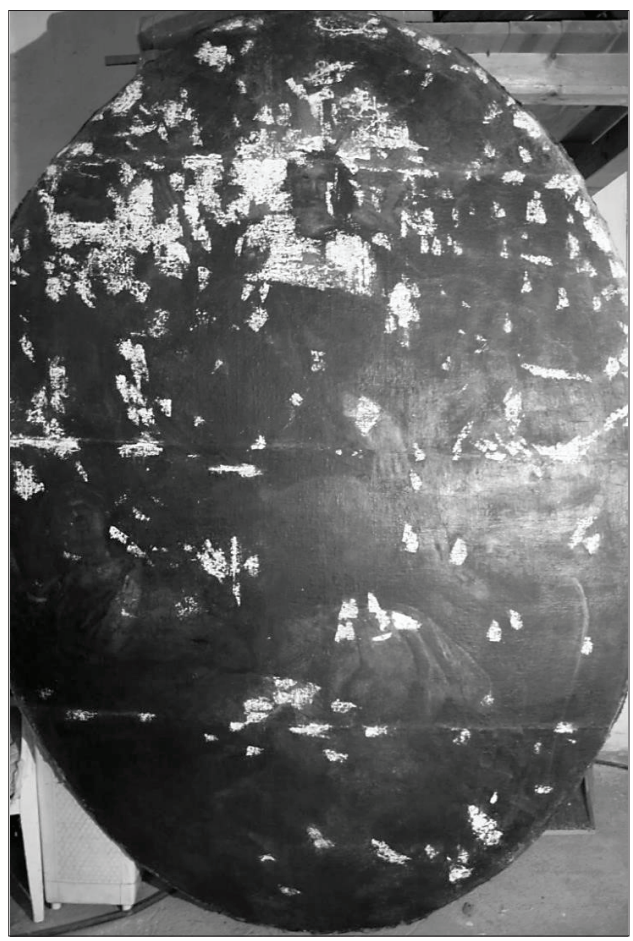

3. M. Stachowicz, Assumption of the Blessed Virgin Mary, the early $19^{\text {th }}$ century, during the conservation works. Photo credit: B. Kuś

gluing back the thorn parts, removing several layers of varnish, retouching and putty-filling the mortar and painting layer, and making a new support of the painting. In the last stage, the loss of paint was filled with carefully selected lime and adhesive putties, which were subsequently retouched and final varnish coat was applied to protect the paining from dust, dirt, UV radiation and humidity. A new, non-invasive suspensions of the canvas were also $\operatorname{added}^{18}$.

The painting in question was done using the oil-on-linen technique and attached to wooden boards on the ceiling with small clouts. It has a shape of tondo and dimensions of approx. $185 \times 250 \mathrm{~cm}^{19}$. The scene is enclosed in a painted frame adorned with motifs of astragal, acanthus leaves in the form of palmette and campanula. In the upper part of the composition, Mary is depicted sitting on the cloud, facing left en trois quarts, with her head straight. The woman has a face of a virgin with regular features, a straight nose, prominent an closed lips. Her eyes are large, hazel brown, gazing at the space - full of sadness and melancholy. The long, dark hair covered with a veil falls in soft waves over her shoulders. She has a luminous aureole around her head and a wreath of 12 stars (two

18 The Parish Archive in Rembieszyce, Program prac konserwatorskich przy polichromii prezbiterium kościoła parafialnego w Rembieszycach, eds A. Adamska-Kuś, B. Kuś, September 2016, no page.

19 The information obtained on September 28, 2017 by courtesy of Ms Aleksandra Adamska-Kuś, to whom I would like to express my sincere gratitude. Z. Michalczyk, op. cit., vol. II, p. 128 quotes slightly different measurements (approx. $300 \times 200 \mathrm{~cm}$ ). 
of them are not visible). Mary is wearing a simple dress cut out at the neck and a rumpled and windblown coat. Her right arm is bent at the elbow and raised up in a greeting gesture. The left arm is slightly bent and moved to the side. Two angels are floating below her, clad in the folds of draperies. The angel on the left side of the canvas is shown en face, has dark curly hair, his eyes are pointed upwards, and his hands are stretched out in a pleading gesture. Only his upper body is visible, the lower part is enveloped in clouds. The angel on the other side is presented in a three-quarter pose with his head straight up. He has bright wavy hair, a round face, slightly negroid features, his eyes are turned to the viewers. In his outstretched hands he hold branches - most probably of acanthus, handing them over to Mary.

The work was painted sketchily, with quick strokes of the brush. It is characterized by the use of a toned-down color scheme. The woman's dress is of ivory color with a tint of grey, while her coat and veil are dark blue. The robes of angels are in the color of light and dark ochre, similarly to the lower section of the background, and unlike the upper part of it which is olive-grey ${ }^{20}$.

Unfortunately, it was not possible to determine what was the point of reference for this scene. However, the angels bear resemblance to the winged envoys of Heaven from Assumption of the Mother of God which Stachowicz painted for the Camaldolese Church in Bielany, Cracow ca. 1820.

In conclusion, it should be noted that the works of M. Stachowicz in Rembieszyce constitute the only known example of a church which was fully decorated by this artist ${ }^{21}$. It is a real pity that the conservation works of the preserved paintings did not allow to reveal any signature of the master which would serve as an irrefutable evidence of Stachowicz's authorship. The thorough restoration of paintings in the years 2016-2017 brought back their

${ }^{20}$ In one of my previous texts, I wrote that Mary is half-turned to the left and wears a dark green outer garment. This confusion was caused by poor condition of the painting, obstructing the correct reading of the scene. See Z. Anusik, M. Karkoch a, Obrazy Michała Stachowicza $w$ kościele parafialnym $w$ Rembieszycach, [in:] Acta Artis. Studia ofiarowane Profesor Wandzie Nowakowskiej, eds A. Pawłowska, E. Jedlińska, K. Stefański, Łódź 2016, p. 207. See also S. Kamiński, The Parish Church, ref. code 169; WUOZwK, Polichromia Wniebowzięcie Marii, record sheet, ed. C. Ostas, 1986.

${ }^{21}$ Z. Michalczyk, op. cit., vol. I, p. 52. 
vivid colors and former glory. The plafond is no longer unsightly, which the author witnessed herself, and which was caused by numerous repainting, improper conservation works and the passage of time. It is again a feast for the eyes and delights with its beauty.

\section{Bibliography}

\section{HandWRiting SOURCES}

The Diocesan Archive in Kielce (Archiwum Diecezjalne w Kielcach) [ADK]

Akta konsystorskie parafii Rembieszyce 1811-1833, ref. code PR-6/1.

Akta konsystorskie parafii Rembieszyce 1818-1938, ref. code PR-6/2.

Akta kurialne. Protokoły wizytacji dziekańskich 1949-1956, ref. code OD-5/50.

Zbiór dokumentów dotyczących parafii i kościoła w Rembieszycach 1613-1899, ref. code II PR-IV/1.

The State Archive in Kielce

(Archiwum Państwowe w Kielcach)

Wojewódzki Konserwator Zabytków II, ref. code 265.

The Parish Archive in Rembieszyce

(Archiwum parafialne w Rembieszycach)

Program prac konserwatorskich przy polichromii prezbiterium kościoła parafialnego w Rembieszycach, eds A. Adamska-Kuś, B. Kuś, September 2016, no page.

The Voivodship Heritage Monuments Protection Office in Kielce Wojewódzki Urząd Ochrony Zabytków w Kielcach [WUOZwK]

Kościół pw. Świętych Piotra i Pawła w Rembieszycach, record sheet, ed. S. Fiedorczuk, 1987.

Polichromia Wniebowzięcie Marii, record sheet, ed. C. Ostas, 1986.

\section{STudies}

Adamczyk A., Wróbel T., Kościoły drewniane w województwie świętokrzyskim, Kielce 2010.

Anusik Z., Karkocha M., Obrazy Michała Stachowicza $w$ kościele parafialnym $w$ Rembieszycach, [in:] Acta Artis. Studia ofiarowane Profesor Wandzie Nowakowskiej, eds A. Pawłowska, E. Jedlińska, K. Stefański, Łódź 2016, pp. 195-211.

Artymiak A., Mieszkańcy miasta Jędrzejowa $w$ świetle najstarszej księgi metrykalnej (1743-1752), Jędrzejów 1947. 
Borkiewicz S., Linowski Z., Monografia historyczna i gospodarcza powiatu jedrzejowskiego, Kielce 1937.

[Buszard L.], Michał Stachowicz, "Tygodnik Ilustrowany” 1860, No. 28 of March 26, pp. 241-242.

Dobrzycki J., Michał Stachowicz, Kraków 1925.

Grabowski A., Michał Stachowicz i jego prace, "Czas" 1866, No. 167 of July 26, p. 1.

Grabowski A., Wspomnienia Ambrożego Grabowskiego, ed. S. Estreicher, vol. II, Kraków 1909, pp. 130-140.

Grzeszczuk M.W., Stachowicz Stanisław, [in:] Polski słownik biograficzny, vol. XLI, Warszawa-Kraków 2002, pp. 331-332.

Hadamik C., Kalina D., Traczyński E., Miasto i gmina Małogoszcz [Series: Dzieje i zabytki małych ojczyzn, ed. R. Mirowski], Kielce 2006.

Karkocha M., Parafia Rembieszyce 1438-2012. Studium z dziejów społeczności lokalnej, Łódź 2013.

Karkocha M., Zabytki epigraficzne w Rembieszycach z XV-XIX wieku, "Studia Epigraficzne" 2016, vol. VI, pp. 39-61.

Katalog zabytków sztuki w Polsce, vol. III (Województwo kieleckie), ed. J.Z. Łoziński, B. Wolff, issue 3 (Powiat jędrzejowski), ed. T. Przypkowski, Warszawa 1957.

Michalczyk Z., Michał Stachowicz (1768-1825) krakowski malarz między barokiem a romantyzmem, t. I-II, Warszawa 2011.

Mirowski R., Kościoły drewniane: najbardziej polskie..., Warszawa 2005.

Nowobilski J.A., Mecenat artystyczny Jana Pawła Woronicza $w$ Krakowie, Kraków 2002.

Radwan D., Stachowicz Michał Franciszek, [in:] Polski słownik biograficzny, vol. XLI, Warszawa-Kraków 2002, pp. 327-331.

Rastawiecki E., Słownik malarzów polskich tudzież obcych w Polsce osiadłych lub czasowo w niej przebywajacych, vol. II, Warszawa 1851; vol. III, Warszawa 1857.

Rawita-Witanowski M., Dawny powiat chęciński, ed. D. Kalina, Kielce 2001.

Schugt E., Kilka słów o Michale Stachowiczu, "Dwutygodnik literacki" [Kraków] 1845, vol. II, pp. 67-80.

Wiśniewski J., Historyczny opis kościołów, miast, zabytków i pamiątek $w$ Jędrzejowskiem, Mariówka 1930. 